\title{
NOUVELLES DE FRANCE
}

1946 - Création d'un Centre d'Etudes Hydrobiologiques au Centre National de la Recherche Scientifique (Directeur: A. PACAUD)

1948 - Organisation, par le Centre d'Etudes Hydrobiologiques du Centre National de la Recherche Scientifique, d'un Laboratoire permanent, à Gif-sur-Yvette (Seine-et-Oise); inauguration officielle le 17 avril 1948.

- XIIIème Congrès International de Zoologie, à Paris (du 21 au 27 juillet 1948).

1950 - Colloque International d'Ecologie, à Paris (du 20 au 25 février 1950).

- Inauguration des nouveaux laboratoires de la Station Centrale d'Hydrobiologie Appliquée à la Pisciculture (Administration des Eaux et Forêts), à Paris (12, avenue de SaintMandé).

\section{DÉCÈS}

Prof. R. Despax, titulaire de la Chaire d'Hydrobiologie à la Faculté des Sciences de Toulouse, décédé en avril 1950.

Prof. L. Leger, de la Faculté des Sciences de Grenoble. L'un des représentants les plus marquants et les plus agissants de l'hydrobiologie française contemporaine, décédé le 7 juillet 1948.

F. ANGEL, Assistant honoraire au Muséum (Laboratoire d'Erpotologie), décédé en juillet 1950.

\section{N E W S}

The Cranbrook Institute of Sciences, Bloomfield, Michigan, announces the following publication:

ALGAE OF THE WESTERN GREAT LAKES AREA, by G. W. Prescott.

A complete guide in which the algae of Michigan and Wisconsin (exclusive of diatoms and desmids) are described, keyed and illustrated. 940 pages, over 1.000 illustrations, a bibliography of 49 pages. Ready before September 1, 1951.

Price $\$ 10.50$. 